\title{
A Child with Seckel Syndrome and Arterial Stenosis: Case Report and Literature Review
}

This article was published in the following Dove Press journal:

International Medical Case Reports Journal

\author{
Minoo Saeidi ${ }^{1}$ \\ Morteza Shahbandari ${ }^{2}$ \\ 'Department of Pediatrics, Imam Hossein \\ Children Hospital, Isfahan University of \\ Medical Sciences, Isfahan, Iran; \\ ${ }^{2}$ Department of Vascular Surgery, Isfahan \\ University of Medical Sciences, Isfahan, \\ Iran
}

Background: Seckel syndrome is a rare genetic disorder with autosomal recessive inheritance. It is characterized by dysmorphic features, intrauterine and postnatal growth restriction, microcephaly and mental retardation. Although cardiovascular complications are not prevalent in this syndrome, severe sinus bradycardia, hypertension and brain vasculopathy are reported. Here, for the first time, we describe a case of lower extremity arterial occlusion in a case of Seckel syndrome.

Case Presentation: An 8-year-old girl with the characteristic features of Seckel syndrome was admitted to the children's hospital with the complaint of left lower extremity pain and a deep ulcer on her left shin. On examination, the left extremity was cooler than the other side, with a bluish color. Dorsalis pedis and popliteal artery pulses were not palpable on the left. A wound measuring 3 by $5 \mathrm{~cm}$ with gangrenous margins was visible on the anterior surface of the left leg. Severe stenosis in the left superficial femoral artery was reported on angiography. Considering the lean body of the patient, angioplasty was not possible and conservative wound care, analgesic drugs and aspirin were recommended.

Conclusion: Clinicians should be suspicious of vascular complications in patients with Seckel syndrome, even in the absence of any other risk factors.

Keywords: Seckel syndrome, microcephalic primordial dwarfism, bird-headed dwarfism, cardiovascular abnormalities, case report

\section{Introduction}

Seckel syndrome (MIM 210600) was first described by Seckel in 1960 as a set of symptoms such as proportionate severe short stature, moderate to severe mental retardation, beaky and protruding nose, micrognathia, large eyes, malformed ears, narrow face and microcephaly. ${ }^{1}$ This is a very rare genetic syndrome with high heterogeneity. A variety of mutations have been reported as the underlying genetic basis of the syndrome, raising hopes for the emergence of gene therapy strategies. ${ }^{2,3}$

Cardiovascular manifestations are not common in this syndrome. ${ }^{4}$ However, severe sinus bradycardia, ${ }^{4}$ malignant hypertension ${ }^{5,6}$ and moyamoya-like vasculopathy of the brain ${ }^{7}$ are reported. Here, we describe the first case of Seckel syndrome from Iran with a new type of vascular involvement, namely superficial femoral artery stenosis.

\section{Case Presentation}

An 8-year-old girl was admitted to our general ward because of left lower extremity pain and ulceration. In outpatient visits she received analgesics as it was assumed that the pain was musculoskeletal. The chief complaint had begun 80 days prior to
Department of Pediatrics, Faculty of

Medicine, Isfahan University of Medical

Sciences, Hezar-Jarib Ave, Isfahan 81746-

7346I, Iran

Tel +98 313-33866266

Email msaeidi@med.mui.ac.ir 
presentation. Left leg pain gradually increased from a simple sore foot only after playing or walking to a severe continuous pain that became aggravated during the night. At first, the skin over the shin became scaly, then erythema and ulcer appeared. The girl's parents denied any recent trauma.

The patient was born at 28 weeks' gestational age with $570 \mathrm{~g}$ weight and $29 \mathrm{~cm}$ height. There was no history of exchange or umbilical catheterization in the neonatal period. Expect for a delay in speaking, the rest of her developmental milestones were normal. The postnatal hearing screening test was normal. Growth parameters were always undesirable. At the age of 2 years, she experienced a prolonged seizure and right hemiplegia due to a cerebrovascular accident. Thrombophilia was not diagnosed when the accident happened, but aspirin and enoxaparin were started. After that, phenobarbital was started because of convulsions, but since drug tapering was associated with stuttering and prolonged aphasia, the drug was continued. She was the third child of non-related parents. The other children were normal.

On physical examination, she was a sweet girl interested in socializing. Her general condition was good but she seemed tired and sad, because of difficulty in falling asleep for a long time. Her head circumference, weight and height measurements were $35 \mathrm{~cm}, 7 \mathrm{~kg}$ and $77 \mathrm{~cm}$, respectively. Her bird-like face was remarkable. Her hair was sparse and thin. Her skin was highly pigmented. There was no pallor or jaundice (Figure 1A and B). Body temperature was within the normal range. Other vital signs, including blood pressure and level of consciousness, were normal.

The left foot was cool and bluish compared to the other side. The dorsalis pedis pulses of both extremities were not detectable. The popliteal artery pulse was not detectable on the left side but the right side was normal. Femoral pulses were normally palpable. No edema or varicose veins were apparent. The skin of the left extremity was shiny and a 5 by $3 \mathrm{~cm}$ corrosive ulcer with well-demarcated and gangrenous margins was evident on the shin. The ulcer bed was white and dark red without any obvious secretion (Figure 1C). There were also two smaller wounds on the fourth toe and anterior aspect of the knee on the same side. The ankle brachial index was 0.2 and the resting ankle pressure was $40 \mathrm{mmHg}$. Oxygen saturation was $35 \%$ and $95 \%$ in the left and right toes, respectively.

Sensory system examinations of both legs were normal at the level of patient cooperation. However, the patient complained about a burning sensation in the left extremity. The muscle strength of the right upper and lower limbs was slightly lower than that of the left, because of the previous cerebral cardiovascular event. Her heart, lungs and abdomen were normal.

Since we were suspicious of a vascular problem according to the history and physical examination, we urgently asked for a consultation with a vascular surgeon and ordered Doppler ultrasound and limb angiography. Doppler ultrasound revealed a monophasic spectral wave and low peak systolic velocity in the left limb. In parallel, CT angiography confirmed long segmental narrowing and significant stenosis in the left superficial femoral artery (Figure 1D).

The potential complications of endovascular surgery in such a patient with small vasculature were described to the parents and they did not consent to surgical intervention. On the other hand, there is not sufficient evidence on the safety and efficacy of several medical treatments in pediatrics. Therefore, conservative wound care, organ placement at the level of heart, aspirin and better nutrition were recommended.
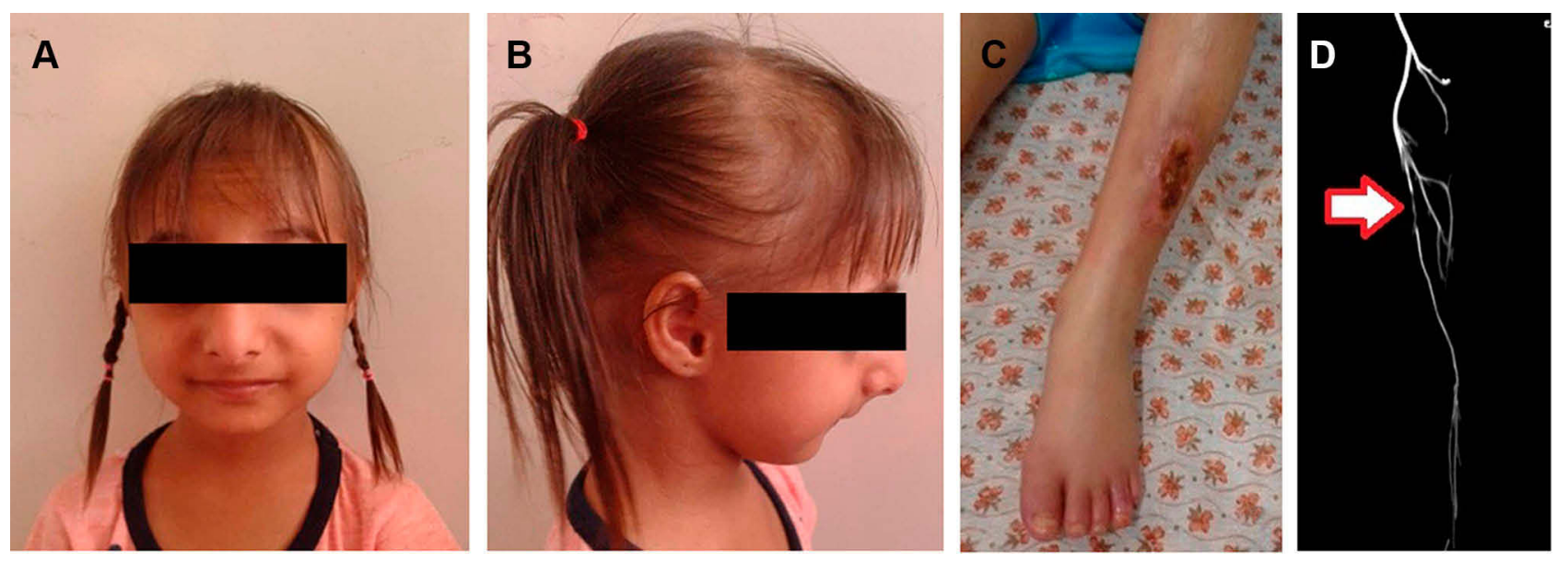

Figure I Bird-like face, retrognathia, microcephaly and thin hairs were prominent in frontal (A) and lateral (B) views. An erosive ulcer was evident on the left shin (C). The left superficial femoral artery was stenotic, as revealed by CT angiography and shown with a white arrow (D). 
On the follow-up visit, the condition of the wound had improved. The patient's mood, appetite and sleep were not acceptable, so a psychological consultation was requested.

\section{Discussion}

Bird-headed dwarfism or Seckel syndrome is a rare genetic syndrome characterized by intrauterine growth restriction, postnatal growth delay, microcephaly, mental retardation and dysmorphic features. ${ }^{8}$ The prevalence of the disorder is less than 1:10,000 live births. ${ }^{9}$ Although the mode of inheritance is autosomal recessive, in parallel with our observation, cases have been reported in non-consanguineous families. ${ }^{2}$ This type of inheritance can occur through heterozygous mutations and has more severe phenotypes. ${ }^{10}$

Aberrations of a variety of genes can lead to Seckel syndrome, ${ }^{2,3}$ most of which are related to the DNA damage response; ${ }^{11}$ this can explain the high incidence rate of hematological abnormalities such as myelodysplastic syndrome

Table I Reported Cardiovascular Complications in Seckel Syndrome

\begin{tabular}{|c|c|c|c|c|c|c|}
\hline $\begin{array}{l}\text { Patient } \\
\text { Profile }\end{array}$ & Complications & $\begin{array}{l}\text { Cardiovascular } \\
\text { Involvements }\end{array}$ & $\begin{array}{l}\text { Diagnostic } \\
\text { Method }\end{array}$ & Treatment & Outcome & Ref. \\
\hline 16-year-old girl & $\begin{array}{l}\text { Persistent } \\
\text { headache, hand } \\
\text { and face } \\
\text { numbness }\end{array}$ & $\begin{array}{l}\text { Moyamoya-like } \\
\text { vasculopathy }\end{array}$ & Angiography & $\begin{array}{l}\text { Surgical } \\
\text { revascularization } \\
\text { as pial synangiosis }\end{array}$ & $\begin{array}{l}\text { Died I year later due } \\
\text { to enlarged cranial } \\
\text { aneurysm }\end{array}$ & Codd et $\mathrm{al}^{26}$ \\
\hline 9-year-old boy & $\begin{array}{l}\text { Left hemiparesis, } \\
\text { CKD }\end{array}$ & $\begin{array}{l}\text { Malignant HTN, } \\
\text { polyarteritis } \\
\text { nodosa }\end{array}$ & Angiography & $\begin{array}{l}\text { Antihypertensive } \\
\text { drugs, } \\
\text { prednisolone, } \\
\text { hemodialysis }\end{array}$ & Not indicated & Kutlu et $a^{27}$ \\
\hline 10-year-old boy & Seizure and coma & $\begin{array}{l}\text { Cerebral artery } \\
\text { aneurysm, } \\
\text { hypertension }\end{array}$ & Angiography & $\begin{array}{l}\text { Antihypertensive } \\
\text { drugs, } \\
\text { embolization }\end{array}$ & $\begin{array}{l}\text { Clinical improvement } \\
\text { with remnant } \\
\text { moderate aphasia }\end{array}$ & $\begin{array}{l}\text { Di Bartolomeo } \\
\text { et } \mathrm{al}^{5}\end{array}$ \\
\hline 16-year-old boy & $\begin{array}{l}\text { Recurrent } \\
\text { syncope }\end{array}$ & $\begin{array}{l}\text { Intermittent } \\
\text { severe } \\
\text { bradycardia }\end{array}$ & Holter monitoring & $\begin{array}{l}\text { Permanent } \\
\text { pacemaker }\end{array}$ & $\begin{array}{l}\text { Well without } \\
\text { recurrence }\end{array}$ & Ramasamy et $\mathrm{al}^{4}$ \\
\hline 12-year-old boy & $\begin{array}{l}\text { Left-sided } \\
\text { Horner } \\
\text { syndrome }\end{array}$ & $\begin{array}{l}\text { Middle cerebral } \\
\text { artery aneurysm }\end{array}$ & MRA & $\begin{array}{l}\text { Endovascular } \\
\text { surgery }\end{array}$ & Clinical improvement & Gunesli et $\mathrm{al}^{24}$ \\
\hline 19-year-old boy & $\begin{array}{l}\text { Dilated } \\
\text { cardiomyopathy, } \\
\text { nephrosclerosis, } \\
\text { headache }\end{array}$ & $\begin{array}{l}\text { Malignant } \\
\text { hypertension }\end{array}$ & $\begin{array}{l}\text { Echocardiography, } \\
\text { autopsy }\end{array}$ & $\begin{array}{l}\text { Antihypertensive } \\
\text { drugs }\end{array}$ & $\begin{array}{l}\text { Died } 2 \text { days after } \\
\text { discharge due to } \\
\text { ruptured cranial } \\
\text { aneurysm }\end{array}$ & Sorof et $\mathrm{al}^{6}$ \\
\hline 13-year-old boy & $\begin{array}{l}\text { Palpitations, easy } \\
\text { fatigability }\end{array}$ & $\begin{array}{l}\text { Incomplete } \\
\text { atrioventricular } \\
\text { canal, pulmonary } \\
\text { HTN }\end{array}$ & Echocardiography & Not indicated & Not indicated & Ucar et $\mathrm{al}^{28}$ \\
\hline 18-year-old girl & $\begin{array}{l}\text { Spontaneous } \\
\text { subarachnoid } \\
\text { hemorrhage }\end{array}$ & $\begin{array}{l}\text { Moyamoya-like } \\
\text { vasculopathy }\end{array}$ & $\begin{array}{l}\text { MRA, cerebral } \\
\text { angiography }\end{array}$ & Palliative care & Improvement & Rahme et $\mathrm{al}^{7}$ \\
\hline Newborn boy & $\begin{array}{l}\text { Cardiac murmur } \\
\text { in examination }\end{array}$ & TOF & Echocardiography & Not indicated & Not indicated & Can et al ${ }^{9}$ \\
\hline 16-year-old girl & $\begin{array}{l}\text { Abrupt-onset } \\
\text { coma }\end{array}$ & $\begin{array}{l}\text { Multiple } \\
\text { intracranial } \\
\text { aneurysms }\end{array}$ & Angiography & $\begin{array}{l}\text { Surgical } \\
\text { intervention }\end{array}$ & $\begin{array}{l}\text { Clinical improvement } \\
\text { with mild left } \\
\text { hemiparesis }\end{array}$ & $\mathrm{D}^{\prime}$ Angelo et $\mathrm{al}^{29}$ \\
\hline
\end{tabular}

Abbreviations: CKD, chronic kidney disease; HTN, hypertension; MRA, magnetic resonance angiography; TOF, tetralogy of Fallot. 
and acute myeloid leukemia in affected individuals. ${ }^{12}$ Among the reported genetic abnormalities are mutations in ataxia telangiectasia and $\operatorname{Rad} 3$ genes, which contribute to an increased number of centrosomes in mitotic cells, more nuclear fragmentation, G2/M arrest and increased micronucleus formation. ${ }^{13}$ Centrosomes are very important in cell cycle regulation, correct segregation of chromosomes and spindle orientation in the mitosis phase, and, in particular, have a very important role in brain tissue. ${ }^{14}$ In addition, RING finger protein TRAIP is proposed to be involved in the pathogenesis of Seckel syndrome. This protein is essential for the stability and integrity of genome structure. ${ }^{15}$ Understanding the underlying molecular mechanisms of this disease opens the way for novel treatment strategies; for example, Scalet et al have proposed two RNA-based therapies for this syndrome. ${ }^{3}$

The diagnosis of this syndrome is mainly based on clinical findings. ${ }^{16}$ However, pregestational consultation and genetic diagnosis are of particular importance as the next offspring of a family with a known case of Seckel syndrome has a $25 \%$ chance of being affected. ${ }^{17,18}$ Intrauterine ultrasound features, including abnormal head appearance, extreme microcephaly, cystic hygroma, encephalocele, posterior fossa cysts, cortical dysplasia and corpus callosum agenesis, can also be exploited for prenatal diagnosis. ${ }^{18}$ In addition, fetal MRI can show brain migration disorders and 3D sonography helps in the diagnosis. ${ }^{17,18}$

Although Seckel syndrome is defined by classical characteristics, other abnormalities have also been reported, indicating that this syndrome is heterogeneous. In line with two previous reports, ${ }^{19,20}$ skin hyperpigmentation was significant in our case. In addition, severe retinal detachment probably due to chorioretinal degeneration has been reported in this syndrome, so the risk of sudden-onset loss of vision should be considered in the care of these patients. ${ }^{21}$ Dental care is also very important in this syndrome because gingival hyperplasia, significant dental crowding, enamel hypoplasia and early loss of permanent teeth have been described. ${ }^{22,23}$

A variety of cardiovascular complications have been reported in Seckel syndrome (Table 1). The case presented here has a history of a non-thrombotic cerebrovascular accident at the age of 2 years. Although not fully evaluated at the time, the event could potentially be described by a moyamoyalike vasculopathy, based on previous studies. ${ }^{7,24}$ To the best of our knowledge, the observation of peripheral vessel stenosis reported here has not been previously described. According to the type of stenosis, surgery was the best option for our patient. $^{25}$ Unfortunately, because of growth restriction and the small size of vessels, endovascular surgical interventions are very difficult in these patients. ${ }^{24}$

In conclusion, Seckel syndrome can present with a variety of clinical manifestations, including peripheral vascular complications.

\section{Ethics and Consent Statement}

Written informed consent was obtained from the parents to have the case details and any accompanying images published. Ethical approval for this report was obtained from Isfahan University Ethics Committee (IR.MUI.RESEARCH. REC.1398.739).

\section{Acknowledgments}

The authors thank Dr. Abolfazl Taheri for his great comments and the parents of the patient for their support.

\section{Disclosure}

The authors report no conflicts of interest in this work.

\section{References}

1. Majewski F, Ranke M, Schinzel A, Opitz JM. Studies of microcephalic primordial dwarfism II: the osteodysplastic type II of primordial dwarfism. Am J Med Genet. 1982;12(1):23-35. doi:10.1002/ ajmg. 1320120104

2. Faivre L, Le Merrer M, Lyonnet S, et al. Clinical and genetic heterogeneity of Seckel syndrome. Am J Med Genet. 2002;112 (4):379-383. doi:10.1002/ajmg.10677

3. Scalet D, Balestra D, Rohban S, et al. Exploring splicing-switching molecules for Seckel Syndrome therapy. Biochim Biophys Acta Mol Basis Dis. 2017;1863(1):15-20. doi:10.1016/j.bbadis.2016.09.011

4. Ramasamy C, Satheesh S, Selvaraj R. Seckel syndrome with severe sinus bradycardia. Indian J Pediatr. 2015;82(3):292-293. doi:10.10 07/s12098-014-1568-3

5. Di Bartolomeo R, Polidori G, Piastra M, Viola L, Zampino G, Chiaretti A. Malignant hypertension and cerebral haemorrhage in Seckel syndrome. Eur J Pediatr. 2003;162(12):860-862. doi:10.10 07/s00431-003-1310-z

6. Sorof JM, Dow-Smith C, Moore PJ. Severe hypertensive sequelae in a child with Seckel syndrome (bird-like dwarfism). Pediatr Nephrol. 1999;13(4):343-346. doi:10.1007/s004670050623

7. Rahme R, Crevier L, Dubois J, Mercier C. Moyamoya-like vasculopathy and Seckel syndrome: just a coincidence? Childs Nerv Syst. 2010;26(7):983-986. doi:10.1007/s00381-010-1142-x

8. Shanske A, Caride DG, Menasse-Palmer L, Bogdanow A, Marion RW. Central nervous system anomalies in Seckel syndrome: report of a new family and review of the literature. Am J Med Genet. 1997;70(2):155-158. doi:10.1002/(SICI)1096-8628(19970516)70:2< 155::AID-AJMG10>3.0.CO;2-I

9. Can E, Bulbul A, Uslu S, et al. A case of Seckel syndrome with tetralogy of fallot. Genet Couns. 2010;21(1):49-51.

10. Yigit G, Brown KE, Kayserili H, et al. Mutations in CDK5RAP2 cause Seckel syndrome. Mol Genet Genomic Med. 2015;3(5):46 7-480. doi:10.1002/mgg3.158

11. Dincer T, Yorgancioglu-Budak G, Olmez A, et al. Analysis of centrosome and DNA damage response in PLK4 associated Seckel syndrome. Eur J Hum Genet. 2017;25(10):1118-1125. doi:10.1038/ ejhg.2017.120 
12. Vascone C, Di Meglio F, Di Meglio L, et al. Antenatal diagnosis of Seckel Syndrome: a rare case report. J Prenat Med. 2014;8 (3-4):70-72.

13. Alderton GK, Joenje $H$, Varon $R$, Borglum AD, Jeggo PA, O'Driscoll M. Seckel syndrome exhibits cellular features demonstrating defects in the ATR-signalling pathway. Hum Mol Genet. 2004;13 (24):3127-3138. doi:10.1093/hmg/ddh335

14. Nano M, Basto R. Consequences of centrosome dysfunction during brain development. Adv Exp Med Biol. 2017;1002:19-45.

15. Chen Y, Li J, Cao F, et al. Nucleolar residence of the seckel syndrome protein TRAIP is coupled to ribosomal DNA transcription. Nucleic Acids Res. 2018;46(19):10119-10131. doi:10.1093/nar/gky775

16. Sisodia R, Raj RK, Goel V. Seckel syndrome: a rare case report. J Indian Soc Pedod Prev Dent. 2014;32(2):160-163. doi:10.4103/ 0970-4388.130983

17. Gupta A, Fazal TS, Arora R. Antenatal diagnosis of seckel syndrome. J Obstet Gynaecol India. 2014;64(Suppl 1):6-8. doi:10.1007/s13224012-0339-1

18. Akkurt MO, Pakay K, Akkurt I, Temur M, Korkmazer E. Prenatal diagnosis of Seckel syndrome at 21 weeks' gestation and review of the literature. J Matern Fetal Neonatal Med. 2019;32(11):1905-1908. doi:10.1080/14767058.2017.1419467

19. Fathizadeh A, Soltani K, Medenica M, Lorincz AL. Pigmentary changes in Seckel's syndrome. J Am Acad Dermatol. 1979;1(1) 52-54. doi:10.1016/S0190-9622(79)70004-1

20. Kilic A, Cakmak SK, Tuncali T, et al. Seckel syndrome with cutaneous pigmentary changes: two siblings and a review of the literature. Postepy Dermatol Alergol. 2015;32(6):470-474. doi:10.51 14/pdia.2015.56102
21. Krzyzanowska-Berkowska P, Szumny D, Mlynczak T, Kisza K, Oficjalska J. Bilateral retinal detachment in Seckel syndrome. Can J Ophthalmol. 2014;49(5):e130-1. doi:10.1016/j.jcjo.2014.07.013

22. Ramalingam K, Kaliyamurthy SD, Govindarajan M, Swathi S. Seckel syndrome: a report of a case. J Indian Soc Pedod Prev Dent. 2012;30 (3):258-261. doi:10.4103/0970-4388.105021

23. Regen A, Nelson LP, Woo SB. Dental manifestations associated with Seckel syndrome type II: a case report. Pediatr Dent. 2010;32 (5):445-450.

24. Gunesli A, Andic C, Alkan O, Erol I, Suner HI. endovascular treatment of a patient with moyamoya disease and Seckel syndrome: a case report. J Pediatr Neurosci. 2018;13(2):245-248. doi:10.4103/ JPN.JPN_96_17

25. Wright LB, Matchett WJ, Cruz CP, et al. Popliteal artery disease: diagnosis and treatment. Radiographics. 2004;24(2):467-479. doi:10. 1148/rg.242035117

26. Codd PJ, Scott RM, Smith ER. Seckel syndrome and moyamoya. $J$ Neurosurg Pediatr. 2009;3(4):320-324. doi:10.3171/2008.12.PEDS 08205

27. Kutlu R, Alkan A, Kutlu O, Yakinci C. Seckel syndrome with polyarteritis nodosa. Indian Pediatr. 2004;41(11):1158-1161.

28. Ucar B, Kilic Z, Dinleyici EC, Yakut A, Dogruel N. Seckel syndrome associated with atrioventricular canal defect: a case report. Clin Dysmorphol. 2004;13(1):53-55. doi:10.1097/00019605-20040100000017

29. D'Angelo VA, Ceddia AM, Zelante L, Florio FP. Multiple intracranial aneurysms in a patient with Seckel syndrome. Childs Nerv Syst. 1998;14(1-2):82-84. doi:10.1007/s003810050181

\section{Publish your work in this journal}

The International Medical Case Reports Journal is an international, peer-reviewed open-access journal publishing original case reports from all medical specialties. Previously unpublished medical posters are also accepted relating to any area of clinical or preclinica science. Submissions should not normally exceed 2,000 words or 4 published pages including figures, diagrams and references. The manuscript management system is completely online and includes a very quick and fair peer-review system, which is all easy to use. Visit http://www.dovepress.com/testimonials.php to read real quotes from published authors. 